ISSN 2414-1143

Научный альманах стран Причерноморья. 2019. Том 17. № 1

DOI 10.23947/2414-1143-2019-17-1-20-25

UDC 008:261.2+27:394

\title{
THE CULTURAL AND HISTORICAL ANALYSIS OF SLAVIC RELIGION IN THE CONTEXT OF THE ETHNOGRAPHIC RESEARCH
}

\author{
(C) Vadim N. Goncharov, Olga lu. Kolosova
}

\author{
North Caucasian federal university. Krasnodar University of the Ministry \\ of Internal Affairs of the Russian Federation, Stavropol branch, Russian Federation \\ science-almanac@mail.ru
}

It is proved in this article that ethnographic researches represent one of the components of scientific cultural and historical research of social development. According to the authors, not only cultural artifacts but also many other ones are infused with religious attitude and more with associations of religious character. All these artifacts reflect ideological aspects of consciousness formation, the system of behavior and relationship of people. The tradition force, selectivity and the normalizing nature of national culture allowed remaining some ancient plots so that they can be a source of replenishment of data on pre-Christian religious views of the Slavs. Understanding the initial semantics of these plots and disclosing their value are possible only with attraction of comparative data on beliefs and ceremonies, with application of various historical evidences and the most ancient historical monuments. All this can be historically comprehended only taking into account the ancient pagan world outlook. The Slavic paganism is a part of the huge universal complex including the most ancient beliefs, ceremonies and mythology that served as a component of the latest world religions. The church treated paganism as an antithesis to Christianity that has nothing in common with the true situation, with science about religion. Historians, religion scholars, archeologists and ethnographers proved that the Christian church, fighting against local cults, nevertheless, absorbed them and included in its dogma, agreeing with insufficient integrity and logic of the turning-out synthesis. The characteristic of religion in general is that with emergence of new representations the old ones do not disappear, and continue to exist along with new even if contradict them.

Keywords: culture, belief, pagan cults, religion, religious consciousness, society.

\section{[В.Н. Гончаров, О.Ю. Колосова Культурно-исторический анализ славянской религии в контексте этнографического исследования]}

В статье обосновывается, что этнографические исследования представляет собой одну из составных частей научного культурно-исторического исследования общественного развития. По мнению авторов, религиозным мироощущением и тем более ассоциациями религиозного характера проникнуты не только культурные артефракты, но и многие другие, также отражающие идеологические аспекты формирования сознания, систему поведения и взаимоотношения людей. Сила традиции, избирательность и нормирующий характер народной культуры позволили сохраниться некоторым древним сюжетам настолько, что они могут служить источником пополнения сведений о дохристианских религиозных воззрениях славян. Понять первоначальную семантику этих сюжетов и раскрыть их значение можно лишь с привлечением сравнительных данных о верованиях, обрядах, с применением разнообразных исторических свидетельств и древнейших исторических памятников. Все это может быть исторически осмыслено только с учетом древнего языческого миропонимания. Славянское язычество - часть огромного общечеловеческого комплекса, включающего древнейшие верования, обряды, мифологию, послужившие составной частью позднейших мировых религий. Церковь трактовала язычество как антитезу христианству, что не имеет ничего общего с истинным положением вещей, с наукой о религии. Историками, религиоведами, археологами, этнографами доказано, что христианская церковь, борясь с местными культами, тем не менее, впитывала их, включала в свое вероучение, соглашаясь с недостаточной целостностью и логичностью получавшегося синтеза. Характерной особенностью религии вообще является то, что с возникновением новых представлений старые не исчезают, а продолжают существовать наряду с новыми, даже если находятся в противоречии с ними.

Ключевые слова: культура, вера, языческие культы, религия, религиозное сознание, общество.

Vadim N. Goncharov - doctor of philosophy, associate professor. North Caucasian Federal University, Stavropol, Russian Federation.

Olga Iu. Kolosova - doctor of philosophy, associate professor. Krasnodar University of the Ministry of Internal Affairs of the Russian Federation, Stavropol branch, Russian Federation. 
Гончаров Вадим Николаевич - доктор философрских наук, доцент. Северо-Кавказский федеральный университет, Ставрополь, Российская Федерация.

Колосова Ольга Юрьевна - доктор философрских наук, доцент. Краснодарский университет Министерства внутренних дел Российской Федерации, Ставропольский филиал, Ставрополь, Российская Федерация.

If the ethnographic source is a product of human labor, then the information is surely coded in it. This information anyway, to a greater or lesser extent, directly or indirectly, reflects various sides of historical process of social development, "provides education of the positive attitude towards cultural distinctions" indirectly [3, pp. 7-10]. To understand all this variety, it is necessary to investigate the subject in different cultural and historical aspects, at the different levels, with application of methods of different sciences, depending on the research aims.

By means of data of ethnographic researches, it is possible to approach fuller understanding of some parties of history of pre-Christian religious views of the Slavs "in relation to theoretical problems of the research of religion" [5, pp.15-19]. Their semantics always reflects elements of the world outlook, synchronous with the time of their emergence. Chronologically late phenomena can be earlier, explaining the origin and development of chronologically previous phenomena. In ethnographic literature it was indicated the fact that, for example, life of the people is a source for studying of history of development of pre-Christian representations of people repeatedly. It makes up an integral part of information of an ethnographic source. As it was noted by many researchers, it is the result of collective creativity, it is inseparably linked with the historical fate of these or those peoples and it is a full-fledged historical source. The ethnography allows reconstructing some phenomena of the previous eras to some extent. In this plan, the studying, in particular, of works of amateur and folk arts is of great interest.

Using the works of amateur and folk arts it is possible to give an idea of the agrarian nature of pre-Christian beliefs of the Slavs, of a pantheon of gods, that is of a polytheistic stage of religious consciousness in the studying of which " [...] the important place is taken by the questions connected with the gnosiological status of religion" [11, pp. 31-34].

The arguments of widespread in the past and the occurring still orthodox concepts of historical process have a certain value in the world outlook aspect. Dialectically materialistic interpretation of information of the specified sources makes a contribution to the development of historical process in the works of the orthodox theologians treating, in particular, the introduction of Christianity in Kievan Rus' as the act of pagans' education. The fact of preservation of pagan representations among the nation contradicts the concept of Christianity as a revelation religion. Modern divinity, "emphasizing the influence on the philosopher of the theological ideas of Orthodoxy" [6, pp. 29-31], notes "the influence of Orthodoxy on the formation of the Russian culture" [9, pp. 39-44], seeks to clean the religion from the connection with primitive beliefs and to bring mystical sources of its emergence to the forefront. "Without ... fundamentals of divinity, it is impossible to study the emergence of any field of social sciences and the person" [10, pp. 82-89]. The problem of genesis of a religious form of consciousness and the display of stages of development of the last in the light of modern discoveries therefore are essential. The scientific character can and has to operate in the questions of origin and early forms of religion with the materials of traditional, in Christianity beliefs and cults, substantiated, in particular, in ethnographic sources. The scientific character can and has to operate in the questions of origin and early forms of religion with the materials of traditional, in Christianity beliefs and cults, substantiated, in particular, in ethnographic sources. The interpretation of information of ethnographic sources provides also a possibility of the research of reli- 
gion not only in its early, but also in the modern forms keeping archaic fragments of religious representations and syncretism of national religious consciousness in general, which "are the forms of spiritual and practical development of the world, which express the valuable attitude of the person towards the reality" [4, pp. 9-12].

The amateur and folk arts owing to the ability to keep the most ancient motives are widely used by science as a source on studying of mythological views and beliefs of the people at early stages of its historical development. Such possibility of its use for clarification of the world outlook of people of the past is very interesting, because for the disclosure of this important subject there is a limited circle of other sources. Owing to the specific ability to reflect ancient mythological ideas and beliefs it can supply with the fullest information on this matter. The difficult ideas and views of nature, society and person sometimes are behind the certain plot. Investigating the plot, it is possible to receive data on the world outlook of people of the previous eras. The plot can also be used as a source of information for the solution of many other problems.

Archeologists, ethnographers, historians of culture and art critics pointed to the link of the plots connected with folk art with pre-Christian beliefs repeatedly. The historiography of this problem was already considered in domestic literature therefore there is no need to discuss it in details. Speaking about the pre-revolutionary period, it is possible to note that it was time of accumulation of the facts and the beginning of their judgment. In Soviet period the new stage of studying of folk art is noted, first of all, by the new methodology of researches. Researches in Soviet period are noted by the aspiration to historicism. In the majority of works the availability of the so-called archaic layer of researches which is the most informative for the history of pre-Christian beliefs of the Slavs is noted. The quite big circle of plots and motives enters this conventional classification unit (the geometrical, vegetational, zoomorphic motives, the plots with anthropomorphous images). As a rule, the certain plots and motives differ in style, on the equipment, in color. The lines which are steadily repeating in different options of archaic layer allow considering the considered directions deeply traditional, connected on the basis with ancient religious mythological ideas of the Slavs.

Pagan semantics is connected with religious and magic representations, with agrarian nature of pre-Christian beliefs of the Slavs. The agricultural communal religion made the dominating form of beliefs and a cult among the Slavic tribes before Christianization. The special place in this system belonged to the represented forces of nature in many respects defining wellbeing of the farmer. After the Christianization of Kievan Rus' the cult of the great gods, the highest mythology, was the least steady, however did not disappear completely. The church combated pagan cults, and they merged in life with Orthodoxy, making a peculiar complex of syncretic representations, reflecting only a particle of this complex, only some elements of the ancient pagan world outlook, their part, the least dangerous for the dominating religion. The church messages confirm effectiveness of pagan beliefs among the population at that time.

As we know, the incessant convertibility is peculiar to the folk art; its motives during centuries-old life are exposed to processing. Nevertheless, the archaic plots which reached our time in a set of options allow to reveal and track the stability of certain lines and to see in them some repeating common places.

Addressing those samples which are the most characteristic for the archaic type or close to it, it is necessary to consider them in terms of the motives and images close to the pagan world outlook. Comparison of plots to ceremonies shows their considerable proximity. The Russian calendar's holidays reflect more ancient stage of anthropomorphize of religious images. They had arisen before the differentiated ideas of deities developed. Using written sources of ceremonial holidays in reconstruction, it is possible not only to give information on pre-Christian representations of the Slavs, but also to tell, to some extent, about the evolution of these representations which was reflected in semantics of sources of different types. 
Discovering a perfect analogy of images with the Slavic gods, obviously, does not matter. Proceeding from that concrete material and also from the extensive literature on this subject it is possible to plan the general way of the development of mythological ideas and to show the stages of evolution of ideas of the pagan deity.

The stability of the anthropomorphous image has undoubted connection with a complex of the pagan religious views. Archaeological and ethnographic parallels show that the main construction material of the East Slavs, except for the southern steppe areas, as we know, was a tree promoting the formation of the image as to the characteristic phenomenon in art. The special role of a tree in everyday life of the Slavic people allows speaking even about a wooden century of the Slavs, meaning not only a utilitarian role of a tree, the main material of construction, production of instruments of labor, but also its specific situation in various ideological constructions. The special role of a birch and an oak is noted in early religious views of the Slavs. All the complex of spring ceremonialism among Russian people was connected with a cult of a birch. The generalizing, symbolical image of a tree, a world tree, served as the embodiment of the concept of the structure of the Universe. Realization in this image of such important categories as idea of space, time, life and death could not but be reflected in the whole complex of the cultural phenomena.

It is important to note the big semantic meaning of an archaic layer. The system of symbolical images expressed concrete natural phenomena in the abstracted form. The feature of the archaic type is not only their saturation with solar signs and space symbols, but also with vegetational motives. The space value of these pagan symbols is disclosed on a set of examples of art of the people of Eurasia and other regions.

Speaking about semantics of the archaic layer, it is necessary to emphasize that not only mythological ideas about the world, but also that positive experience which was gained by the mankind, were reflected in it. Two very important and essential complexes of the concepts, produced as a result of judgment of life experience, arose and were created in extreme antiquity. The first is a concept of geographical coordinates. The concept of recurrence of time was the second important concept.

The possibility of attributions of ethnographic researches gives the grounds for fuller disclosure of the subject connected with genesis of religious views of the Slavs. Approaching studying of sense of images of archaic type, there is an opportunity to consider them not as a senseless set of elements but as a system of views of ancient centuries. Using these researches, it is possible to approach fuller understanding of some sides of history of preChristian religious views of the Slavs. However, the inclusion of a wider historical and cultural context is required that is possible when carrying out the certain parallels by its comparison to other sources of different types, first of all to the archaeological sources. Any little serious reconstruction of history of primitive society demands the synthesis of the facts of ethnography, archeology and others, social and natural sciences, adjacent to them.

The main aim is the extraction of necessary information from the studied sources. On the basis of the analysis of information obtained during the studying, there is an opportunity to judge the religious views, enough remote from us in time, the world outlook and some other features of culture of the society, performing numerous functions. There is "a necessity of consideration ... of these functions and a disposition of social structures" [2, pp. 168-177]. This, to some extent, can be used for reconstruction of both social development, and the personality [7, pp. 15-18] in the context of "formation of new social reality" [8, pp. 64-68]. For illumination of the specified questions it is important to choose objects having the greatest informational content.

In the context of the social and philosophical research of religious forms of society development the following subjects can be disclosed: genesis of religious representations of the Slavs; the agrarian nature of pagan beliefs of the Slavs, including an embodiment of forces of 
nature, their personification, a pagan pantheon of deities; syncretism of national religious views, synthesis of paganism with Christianity [1, pp. 15-23].

\section{Лumepamypa}

1. Бакланов И.С. Роль раннего христианства и нехристианских традиций в развитии европейского интеллектуализма // Научная мысль Кавказа. 2004. № S5. C. 15-23.

2. Бакланова О.А., Бакланов И.С. Современная российская социальность в контексте социального конструкционизма // Вопросы социальной теории. 2015. Т. 7 . № 1-2. C. 168-177.

3. Говердовская E.B. Особенности проектирования образовательного пространства высшей школы в поликультурном регионе // Экономические и гуманитарные исследования регионов. 2014. № 4. С. 7-10.

4. Ерохин А.М. Религия и искусство в системе культуры // European Social Science Journal. 2014. № 7-2 (46). C. 9-12.

5. Ерохин А.М. Культурологический аспект фрормирования религиозного сознания // European Social Science Journal. 2013. № 11-1 (38). C. 15-19.

6. Камалова О.Н. «Созерцание» в философско-культурологических построениях И. Ильина // Гуманитарные и социально-экономические науки. 2012. № 6. С. 29-31.

7. Лобейко Ю.А. Социально-педагогический аспект активности личности в системе общественного развития // Экономические и гуманитарные исследования регионов. 2015. № 1. С. 15-18.

8. Лукьянов Г.И. Трансформационные процессы в современном российском обществе как отражение динамики новой социальной реальности // Экономические и гуманитарные исследования регионов. 2017. № 4. С. 64-68.

9. Матяш Т.П., Несмеянов Е.Е. Православный тип культуры: идея и реальность // Гуманитарные и социально-экономические науки. 2015. № 3 (82). С. 39-44.

10. Месхи Б.Ч., Несмеянов E. E. Теология или лженаука: что на самом деле разрушает отечественное образование // Гуманитарные и социальные науки. 2014. № 4. С. 82-89.

11. Шеффф Г.А., Камалова О.Н. Некоторые аспекты проблемы гносеологического статуса религии в русской религиозной фрилософии: С.Н. Булгаков, П.А. Флоренский, С.Л. Франк // Гуманитарные и социально-экономические науки. 2013. № 4 (71). С. 31-34.

\section{References}

1. Baklanov I.S. Rol' rannego khristianstva i nekhristianskikh traditsii v razvitii evropeiskogo intellektualizma [The role of early Christianity and non-Christian traditions in the development of the European intellectualism]. Nauchnaia mysl' Kavkaza [The Scientific thought of the Caucasus]. 2004. No. S5. pp.15-23 (in Russian).

2. Baklanova O.A., Baklanov I.S. Sovremennaia rossiiskaia sotsial'nost' v kontekste sotsial'nogo konstruktsionizma [Modern Russian sociality in the context of a social constructionism]. Voprosy sotsial'noi teorii [Questions of the social theory]. 2015. V. 7. No. 1-2. pp. 168-177 (in Russian).

3. Goverdovskaya E.V. Osobennosti proektirovaniia obrazovatel'nogo prostranstva vysshei shkoly $v$ polikul'turnom regione [Features of design of educational space of the higher school in the polycultural region]. Ekonomicheskie i gumanitarnye issledovaniia regionov [Economic and humanitarian researches of regions]. 2014. No. 4. pp. 7-10 (in Russian). 
4. Yerokhin A.M. Religion and art in the system of culture. European Social Science Journal. 2014. No. 7-2 (46). pp. 9-12.

5. Yerokhin A.M. Culturological aspect of formation of religious consciousness. European Social Science Journal. 2013. No. 11-1(38). pp. 15-19.

6. Kamalova O.N. "Sozertsanie" $v$ filosofsko-kul'turologicheskikh postroeniiakh I. Il'ina ["Contemplation" in philosophical and culturological creation of I. Ilyin]. Gumanitarnye i sotsial'no-ekonomicheskie nauki [Humanitarian and social and economic sciences]. 2012. No. 6. pp. 29-31 (in Russian).

7. Lobeyko Yu. A. Sotsial'no-pedagogicheskii aspekt aktivnosti lichnosti v sisteme obshchestvennogo razvitiia [Social and pedagogical aspect of activity of the personality in the system of social development]. Ekonomicheskie i gumanitarnye issledovaniia regionov. [Economic and humanitarian researches of regions.]. 2015. No. 1. pp. 15-18 (in Russian).

8. Lukyanov G.I. Transformatsionnye protsessy v sovremennom rossiiskom obshchestve kak otrazhenie dinamiki novoi sotsial'noi real'nosti [Transformational processes in modern Russian society as reflection of dynamics of new social reality]. Ekonomicheskie i gumanitarnye issledovaniia regionov [Economic and humanitarian researches of regions]. 2017. No. 4. pp. 64-68 (in Russian).

9. Matyash T.P., Nesmeyanov E.E. Pravoslavnyi tip kul'tury: ideia i real'nost' [Orthodox type of culture: idea and reality]. Gumanitarnye i sotsial'no-ekonomicheskie nauki. [Humanitarian and social and economic sciences]. 2015. No. 3 (82). pp. 39-44 (in Russian).

10. Meskhi B.Ch., Nesmeyanov E.E. Teologiia ili Izhenauka: chto na samom dele razrushaet otechestvennoe obrazovanie [Theology or pseudoscience: what actually destroys domestic education.]. Gumanitarnye i sotsial'nye nauki [Humanitarian and social sciences]. 2014. No. 4. pp. $82-89$ (in Russian).

11. Scheff G.A., Kamalova O.N. Nekotorye aspekty problemy gnoseologicheskogo statusa religii v russkoi religioznoi filosofii: S.N. Bulgakov, P.A. Florenskii, S.L. Frank [Some aspects of a problem of the gnoseological status of religion in the Russian religious philosophy: S.N. Bulgakov, P.A. Florensky, S.L. Frank]. Gumanitarnye i sotsial'noekonomicheskie nauki [Humanitarian and social and economic sciences]. 2013. No. 4 (71). pp. 31-34 (in Russian). 